\title{
Industrial action by healthcare workers in Nigeria in 2013-2015: an inquiry into causes, consequences and control-a cross-sectional descriptive study
}

Obinna Ositadimma Oleribe ${ }^{1,3^{*}}$, Iheaka Paul Ezieme ${ }^{1}$, Olabisi Oladipo ${ }^{1}$, Ezinne Patience Akinola ${ }^{1}$, Deborah Udofia ${ }^{1}$ and Simon D. Taylor-Robinson ${ }^{2}$

\begin{abstract}
Background: Nigeria has suffered from several healthcare workers' strikes in the past 36 months, involving all categories of health workers. Frequent healthcare workers' strikes result in the closure of public healthcare institutions preventing Nigerians' access to quality health services. The purpose of this study was to identify the root cause(s) of strikes by healthcare workers, their effects on the health system and possible solutions to prevent, or at least reduce, industrial action.

Methods: A cross-sectional descriptive survey was used to execute this study between February and March 2015. A self-administered questionnaire with both closed- and open-ended questions was used for this study. Data were analysed using EpiData ${ }^{\mathrm{TM}}$ and SPSS 21. Simple frequencies and chi-square analysis were carried out.

Results: A total of 150 healthcare workers participated in the study. Sixty-two (41.3\%) participants were males, 86 (57.3\%) married, 90 (60.0\%) Christians and 119 (79.3\%) graduates, and about half of the participants earn less than N129 000.00 (US\$ 737.00) per month. Less than half of the participants (43.6\%) supported industrial actions. Poor healthcare leadership and management were cited as the most common (92\%), as well as the most important (43. $3 \%$ ), cause of healthcare worker strikes in Nigeria. Other causes cited were a demand for higher salaries and wages (82\%), infrastructural issues (63.3\%) and inter-personal issues (61.3\%). Only $2.0 \%$ rated current healthcare management as excellent, while $24.0 \%$ rated it as very good. Several strategies were cited towards improving healthcare management.

Conclusions: The findings of this study differ from previous studies that identified demand for increased salaries and wages as the most common cause of healthcare workers' strikes in Nigeria. Identified causes of these continued strikes, especially inadequate healthcare leadership/management, must be tackled in order to eliminate industrial action by healthcare workers. Training doctors in health management and leadership towards building skilled physician leaders is a strategy that is long overdue in Nigeria.
\end{abstract}

Keywords: Nigeria, Healthcare worker, Strikes, Industrial actions, Health system

\footnotetext{
* Correspondence: obinna.oleribe@expertmanagers.org

${ }^{1}$ Excellence \& Friends Management Care Centre (EFMC), Abuja, Nigeria

${ }^{3}$ No 8, Excellence and Friends Street, Dutse, P. O. Box 200, PSIN901101 Abuja,

Nigeria

Full list of author information is available at the end of the article
} 


\section{Background}

Workers' strikes involve the collective withholding of labour/services by a group of workers for the purpose of extracting certain concessions or benefits and are usually intended for the economic benefits of the strikers [1]. In Nigeria, the law allows all workers to form or join unions, with the exception of members of the armed services, the police force, firefighters, Central Bank employees and customs and excise staff [2]. While the first recorded strike action in history took place during the reign of Ramses III in the twelfth century $\mathrm{BC}$, health workers' strikes have remained commonplace throughout history as well as in Nigeria [3]. The first nationwide strike by the organized workforce in Nigeria was on 21 June 1945 by about 150 000 clerical and non-clerical workers in the Nigerian civil service, demanding better wages in response to the rising cost of living brought about by the Second World War [4]. In the last 36 months, the Nigerian health system has experienced more than eight different strikes involving doctors, nurses and allied healthcare workers [5-10]. These strikes have negatively impacted on the healthcare system, leading to several avoidable deaths, complications and outgoing medical tourism, as the wealthy seek health services abroad [11]. The impact of these strikes is worst when they occur at periods of national health emergencies such as the recent Ebola viral disease outbreak, Lassa fever or cholera outbreaks or even man-made emergencies like Boko Haram suicide bombings with mass casualties [12]. Reasons abound why healthcare workers go on strike in true underlying causes of industrial action Nigeria, and these include career stagnation, perceived discriminatory policies and demoralization from working in systems with poor infrastructure, manpower shortages and poor personal remuneration [3]. However, in recent times, there has been a division of opinion on pinpointing the true underlying causes of industrial action $[1,13]$.

As health workers' strikes continue to be seen and accepted as normal behaviour in the Nigerian heath sector, we decided to study the characteristics of health workers' industrial action in Nigeria. The purpose of this study was to identify the root cause(s) of healthcare worker strikes and their effects on the health system and proffer possible solutions aimed at preventing, or at least reducing, industrial actions. This study also aimed at stimulating discussions amongst health workers and managers on the best grievance management strategies for the healthcare industry and hospital leadership with sustainable improvement in health outcomes.

\section{Methods}

A cross-sectional descriptive survey approach was used to execute this study between February and March 2015. A questionnaire with both closed- and open-ended questions was developed; pre-tested for accuracy, analyzability, acceptability and ambiguity; and used for this study. The study population was selected from the healthcare worker population in Abuja, the Nigerian Federal Capital Territory, which is home to almost 200 government-owned healthcare facilities offering primary, secondary and tertiary healthcare. Six government-owned healthcare facilities (four secondary healthcare facilities, one comprehensive healthcare centre and one primary healthcare centre) were selected by convenience sampling. One hundred and fifty health workers who were met at their duty posts during lunch hour within the premises of their respective hospitals were enlisted for the study. Healthcare workers were adequately informed of the study, and those who agreed to participate were enlisted into the study. Verbal consent was received from all participants prior to the administration of the questionnaires. The questionnaires comprised of 40 questions and were self-administered. Study variables include causes of strikes, their implications and suggested solutions. The completed questionnaires were retrieved from each individual on an agreed date and time and screened for accuracy and completeness.

Data were entered into EpiData ${ }^{\mathrm{m}}$ [14] from where information was exported into SPSS 21 [15] for analysis after data cleaning and validation. Simple frequencies and chi-squares were performed and relevant tables developed. Age, educational qualification, marital status and number of years in service were re-coded for the chi-square analysis. Recoding of variables saw all participants grouped into graduates and non-graduates, married and single (with widows classified as singles), below 5 years in service and 5 years and above and workers below 40 years of age and 40 years of age.

\section{Results}

A total of 150 questionnaires were printed and distributed to healthcare workers, and all were retrieved within the study period, giving a response rate of $100 \%$. The $100 \%$ response rate resulted from the use of a questionnaire with simple questions, which did not take more than $10 \mathrm{~min}$ to fill. An added advantage was that the investigators had an established relationship with the hospitals where the healthcare workers worked. Of the 150 healthcare workers enlisted for the study, 62 (41.3\%) were males. Participants had an age range of 26 to 52 years and average age of 33.9 years (S.D. $=5.36)$. Moreover, $122(83 \%)$ of the 147 indicated their age were less than 40 years old. Of the 150 participants, 86 (57.3\%) were married, 90 (60.0\%) were Christians and 119 (79.3\%) were graduates with either a BSc (106, $70.7 \%)$ or MSc (13, $8.7 \%)$. Income-wise, half of the participants earn less than N129000.00 (US\$ 737.00) per month. Table 1 shows the socio-demographic characteristics of the study participants.

More than half of the respondents $(85,56.7 \%)$ had worked in the health system for less than 5 years with 
Table 1 Socio-demographic characteristics of study participants

\begin{tabular}{llll}
\hline SN & & Number & Percen \\
\hline Gender of participants & & & \\
& Gender & & \\
1 & Male & 62 & 41.3 \\
2 & Female & 88 & 58.7 \\
& Total & 150 & 100
\end{tabular}

Age of respondents

\begin{tabular}{cccc}
\multicolumn{1}{c}{ Ages } & & \\
1 & $25-29$ & 26 & 17.7 \\
3 & $30-34$ & 68 & 46.3 \\
4 & $35-39$ & 28 & 19.0 \\
& $\geq 40$ & 25 & 17.0 \\
& Total & 147 & 100
\end{tabular}

Marital status of participants

Marital status

$\begin{array}{llll}1 & \text { Married } & 86 & 57.3 \\ 2 & \text { Single } & 61 & 40.7 \\ 3 & \text { Widow } & 3 & 2.0 \\ & \text { Total } & 150 & 100\end{array}$

Religion of practice of participants

\begin{tabular}{llll}
\multicolumn{1}{l}{ Religion } & & \\
2 & None & 4 & 2.7 \\
3 & Christianity & 90 & 60.8 \\
& Islam & 54 & 36.5 \\
& Total & 148 & 100
\end{tabular}

Monthly income of participants

Monthly income

$\begin{array}{llll}1 & 10000-49000 & 21 & 14.19 \\ 2 & 50000-89000 & 21 & 14.19 \\ 3 & 90000-129000 & 33 & 22.30 \\ 4 & 130000-169000 & 26 & 17.57 \\ 5 & 170000-199000 & 22 & 14.86 \\ 6 & >199000 & 25 & 16.89 \\ & \text { Total } & 148 & 100\end{array}$

Academic qualification of respondents

\begin{tabular}{lll}
$\begin{array}{l}\text { Highest academic } \\
\text { qualification }\end{array}$ & & \\
$\begin{array}{l}\text { First school leaving } \\
\text { certificate }\end{array}$ & 1 & 0.7 \\
SSCENWAEC & 2 & 1.3 \\
Certificates/diploma & 28 & 18.7 \\
Bachelors & 106 & 70.7 \\
Masters and above & 13 & 8.7 \\
Total & 150 & 100 \\
\hline
\end{tabular}

$70 \%(105)$ in public health service. Physicians constituted $20.7 \%$ of the respondents with nurses and pharmacists constituting $17.3 \%$ each (Table 2). While $76.67 \%$ of the respondents believed that the health system in Nigeria is understaffed, $73.3 \%$ were satisfied with both their current earnings and their working conditions. However, $46 \%$ (69) were facing challenges of human resource shortages in their places of work, poor infrastructure $(36 \%)$ and lack of financial incentives to work $(22.7 \%)$.

When asked about their attitude to health worker strikes, $43.6 \%$ were in support of the industrial actions (Table 3).

\section{Causes of strikes}

Healthcare leadership and management issues were cited as the most common (92\%), as well as the most important (43.3\%), causes of health workers' strikes in Nigeria. Other common causes were demand for higher salaries and wages (82\%), infrastructural issues (63.3\%) and inter-personal issues (61.3\%).

On the scale of importance, inter-professional issues and demand for higher salaries and wages were cited as the second and third most important causes of healthcare workers' industrial action in Nigeria (Table 3).

\section{Implications of strikes}

Respondents also cited disruption of patient care (96.7 \%) as the most common implication of health worker strikes in Nigeria. Perceived consequences and reasons for further discontent were high referral rates to private hospitals $(66.0 \%)$, patient loss to follow-up (56.0\%), mismanagement by alternative healers and high private hospital costs $(17.3 \%)$. Other common effects of strikes by healthcare workers on patients and healthcare systems cited by the respondents were an increase in financial burden on patients; increased morbidity and mortality, especially amongst the poor; collapse of publically funded health facilities; loss of confidence in the health system; unequal access to quality medical care; emigration of qualified health workers; increased spread of contagious diseases; and negative impact on national productivity.

\section{Suggested solutions}

Although all respondents were concerned with the effects of the strikes on patients, they were of the opinion that strengthening of the healthcare system $(82.7 \%)$, improving financial and professional motivation of health workers $(50.7 \%)$ and involving healthcare workers in decision-making (43.3\%) were possible solutions to the plethora of strike action in Nigeria (Table 3). On specific changes in the health industry that would bring about an end to the numerous strikes in Nigeria, the 
Table 2 Occupational history of participants

\begin{tabular}{llll}
\hline \multicolumn{2}{l}{ SN } & Number & Percent \\
\hline \multicolumn{4}{l}{$\begin{array}{l}\text { Number of years in public health system } \\
\text { Years in service }\end{array}$} \\
1 & $<5$ & 85 & 56.67 \\
2 & $5-9$ & 40 & 26.67 \\
3 & $10-14$ & 14 & 9.33 \\
4 & $15-19$ & 9 & 6.00 \\
5 & $20-24$ & 1 & 0.67 \\
6 & $>24$ & 1 & 0.67 \\
& Total & 150 & 100.01
\end{tabular}

Current place of employment of respondents

Current place of employment

$\begin{array}{llll}1 & \text { Public service } & 105 & 70.0 \\ 2 & \text { Private } & 45 & 30.0 \\ & \text { Total } & 150 & 100\end{array}$

Current title in place of employment

$\begin{array}{ll} & \text { Title of respondents } \\ 1 & \text { Doctors } \\ 3 & \text { Nurses } \\ 4 & \text { Pharmacist } \\ 5 & \text { Lab scientist } \\ 6 & \text { Admin officer } \\ 7 & \text { Community ext. worker } \\ 8 & \text { Physiotherapist } \\ 9 & \text { Radiographer } \\ & \text { Optician } \\ & \text { Total }\end{array}$

Respondent who think Nigeria healthcare system is understaffed

$\begin{array}{ll}1 & \text { Nigeria understaffed } \\ 2 & \text { Yes } \\ 3 & \text { No } \\ & \text { Undecided } \\ & \text { Total }\end{array}$

Satisfaction with current earning

Satisfied

Yes

Undecided

No

Total

150

100.01

$\begin{array}{lll}\text { Satisfied } & & \\ \text { Yes } & 110 & 73.3 \\ \text { Undecided } & 21 & 14.0 \\ \text { No } & 19 & 12.7 \\ \text { Total } & 150 & 100\end{array}$

Satisfaction with working conditions

\begin{tabular}{llll}
\multicolumn{5}{l}{ Satisfied } & & \\
1 & Yes & 110 & 73.3 \\
2 & No & 19 & 12.7 \\
3 & Undecided & 21 & 14 \\
& Total & 150 & 100
\end{tabular}

Table 2 Occupational history of participants (Continued)

\begin{tabular}{|c|c|c|c|}
\hline \multicolumn{4}{|c|}{ Problems/difficulties faced in respondents' places of work } \\
\hline & \multicolumn{3}{|l|}{ Problems } \\
\hline 1 & Manpower shortage & 69 & 46.0 \\
\hline 2 & Poor infrastructure & 54 & 36.0 \\
\hline 3 & Lack of incentives & 34 & 22.7 \\
\hline 4 & Stagnation & 16 & 10.7 \\
\hline 5 & Lack of professional development & 13 & 8.7 \\
\hline
\end{tabular}

respondents cited leadership and management (88.7 \%), salaries of workers $(68.0 \%)$, financial management (61.3\%) and infrastructural changes (48.0\%) as crucial. However, when asked to state the most important change each of them would like to see, a change in leadership and management (64.7\%) was said to be the most important factor. Others were improved financial management (13.3 \%) and enhanced salary of workers $(11.3 \%)$ as shown in Table 4. The respondents were of the view that the following would eliminate or prevent the occurrence of health workers' strikes in Nigeria: (1) government sensitivity to the needs and demands of healthcare workers; (2) negotiations with all parties involved; (3) the government taking the agitations of the healthcare sector workers more seriously; (4) salary increase to be effected; (5) changes to labour laws; (6) reduction of corruption and increase in transparency; (7) proper outlining of job descriptions for various healthcare providers; (8) training and re-training of staff to understand the value of efficiency; (9) good interprofessional relationship; and (10) creation of policies that improve the state of health institutions.

When asked to rate the current hospital leadership and management in terms of effectiveness and efficacy, only $2.0 \%$ rated it as excellent, while $24.0 \%$ rated it as very good. The rest, as shown in Table 5 , rated it as just good or average. To improve health system leadership, the respondents suggested periodic evaluation (86.0\%), more training $(84.0 \%)$ and "in-service" management/ leadership training (82.0 \%) for healthcare workers. Only $9.3 \%$ (14) cited pre-service courses as improvement strategies for healthcare leadership. However, $26 \%$ asked that leadership of the health system be open to all healthcare workers. The study went on to ask the participants, "who should lead the health team?" To this question, $54.67 \%$ were of the view that doctors should lead the team, while the rest suggested that any professional $(26.67 \%)$ or health administrator $(18.67 \%)$ could head the medical team (Table 5).

As this study took place during an ongoing health worker strike, the opinions of the healthcare workers were sought on the current strike. While $78.5 \%$ (117) were aware of the reason behind the current strike in 
Table 3 Health workers attitude to strikes in Nigeria

\begin{tabular}{ll}
\hline SN & \\
\hline $\begin{array}{l}\text { Support of strike by health workers } \\
1\end{array}$ & Support for strike \\
2 & No \\
3 & Undecided \\
& Total \\
Suggested common causes of strikes in Nigeria \\
(participants free to name more than one)
\end{tabular}

Table 3 Health workers attitude to strikes in Nigeria (Continued)

\begin{tabular}{llcc}
\hline 2 & $\begin{array}{l}\text { Motivate health workers financially and } \\
\text { professionally }\end{array}$ & 74 & 50.7 \\
3 & Carry workers along in decision making & 65 & 43.3 \\
\hline All were concerned with the effects of the strike on the patients $(150,100 \%)$
\end{tabular}

the country, only $45.0 \%$ (67) agreed to the strike and $45.3 \%$ (68) were of the view that the strike would achieve the desired outcomes (Table 6).

To mitigate the impact of strikes, the respondents had advice for the management and leadership of healthcare institutions and to patients and their relations. To the healthcare workers, it was suggested that they work corporately as a team, understand their patients, put more effort in their work and pursue further postgraduate studies to improve their clinical practice, while working to understand the hierarchy in the healthcare system, improving relationships between medical and nonmedical staff, but making the health of the patients paramount. To the healthcare leadership, it was suggested that conducive working environments be created for staff, in addition to being dedicated to duty, willing to listen to the grievances of healthcare workers, ensuring that due process is followed in relation to promotion and confirmation of staff, ensuring prudent management of available resources, learning to serve and to provide

Table 4 Participants suggested changes or solutions to health workers strikes in Nigeria

\begin{tabular}{llll}
\hline SN & & Number & Percent \\
\hline \multicolumn{2}{l}{ Changes they would want to see } \\
& Changes & \\
1 & Leadership/management & 133 & 88.7 \\
2 & Salaries of workers & 102 & 68.0 \\
3 & Financial management & 92 & 61.3 \\
4 & Infrastructure & 72 & 48.0 \\
5 & Work packages & 17 & 11.3 \\
6 & Promotion guidelines & 12 & 8.0 \\
7 & Guidelines & 7 & 4.7 \\
8 & Ownership of facility & 2 & 1.3 \\
Most important changes they will like to see & & \\
& Most important changes & & \\
1 & Leadership/management & 97 & 64.7 \\
2 & Financial management & 20 & 13.3 \\
3 & Salary of workers & 17 & 11.3 \\
4 & Infrastructure & 7 & 4.7 \\
5 & Work place & 1 & 0.7 \\
6 & Guidelines & 1 & 0.7 \\
7 & Available and affordable system for all & 1 & 0.7 \\
\hline
\end{tabular}


Table $\mathbf{5}$ Leadership of the health institutions, rating and suggested ways of improvement

\begin{tabular}{|c|c|c|c|}
\hline \multirow{2}{*}{\multicolumn{4}{|c|}{$\frac{\mathrm{SN}}{\text { Rating of hospital leadership/management }}$}} \\
\hline & & & \\
\hline \multicolumn{4}{|c|}{ Rating } \\
\hline 1 & Excellent & 3 & 2.0 \\
\hline 2 & Very good & 36 & 24.0 \\
\hline 3 & Good & 101 & 67.3 \\
\hline \multirow[t]{2}{*}{4} & Average & 10 & 6.7 \\
\hline & Total & 150 & 100 \\
\hline \multicolumn{4}{|c|}{ How can health leadership be improved } \\
\hline \multicolumn{4}{|c|}{ Improvement method } \\
\hline 1 & Periodic evaluation & 129 & 86.0 \\
\hline 2 & More training & 126 & 84.0 \\
\hline 3 & In-service management/leadership training & 123 & 82.0 \\
\hline 4 & Open to all health workers & 39 & 26.0 \\
\hline 5 & Pre-service courses & 14 & 9.3 \\
\hline \multicolumn{4}{|c|}{ Most Important of all the improvement methods } \\
\hline \multicolumn{4}{|c|}{ Most important improvement method } \\
\hline 1 & Periodic evaluation & 74 & 49.3 \\
\hline 2 & More trainings & 32 & 21.3 \\
\hline 3 & In-service management/leadership training & 28 & 18.7 \\
\hline 4 & Open to all health workers & 8 & 5.3 \\
\hline 5 & No comments & 8 & 5.3 \\
\hline \multicolumn{4}{|c|}{ Who should be the head of the hospital } \\
\hline \multicolumn{4}{|c|}{ Who should be the head } \\
\hline & Doctors & 82 & 54.67 \\
\hline & Any professional & 40 & 26.67 \\
\hline & Health administrator & 28 & 18.67 \\
\hline & Total & 150 & 100 \\
\hline
\end{tabular}

consensus amongst their team workers and be a little more flexible with the governmental position. To the patients, it was suggested that they create patient associations or defence coalitions and also demand more from the government and healthcare workers with respect to healthcare quality, understand the challenges of healthcare workers and join forces with healthcare workers during strikes to get the government to listen and not to turn against healthcare workers.

To improve hospital management and working conditions, the respondents were of the view that the government should employ more workers, provide better infrastructure, invest more on healthcare, organize seminars and training, monitor the promotion process and root out corruption, while improving staff welfare packages and better equipping the health centres.

All chi-square analyses of various variables were not significant (Table 7).
Table 6 Current strike, knowledge, attitude and practices

\begin{tabular}{lll}
\hline SN & Number & Percent \\
\hline $\begin{array}{l}\text { Knowledge for the reason for present strike } \\
\text { Knowledge of the reason for the present strike }\end{array}$ & & \\
Yes & 117 & 78.5 \\
No & 20 & 13.4 \\
I do not know & 12 & 8.1 \\
$\quad$ Total & 149 & 100 \\
Agreement with the reason for the strike & & \\
$\quad$ Agreed & & \\
Yes & 67 & 45.0 \\
2. No & 54 & 36.2 \\
Undecided & 28 & 18.8 \\
Total & 149 & 100 \\
Do you think the strike will yield desired outcome? & & \\
Will yield desired outcome & & \\
Yes & 68 & 45.3 \\
No & 6 & 4.0 \\
Uncertain & 76 & 50.7 \\
Total & 150 & 100
\end{tabular}

Are union activist beneficial to the overall objective?

Union activist beneficial

$\begin{array}{lll}\text { Yes } & 143 & 95.3\end{array}$

$\begin{array}{lll}\text { No } & 4 & 2.7\end{array}$

Undecided $\quad 3 \quad 2.0$

$\begin{array}{lll}\text { Total } & 150 & 100\end{array}$

Can you boycott the strike for the sake of patients?

Can boycott strike

$\begin{array}{lcc}\text { Yes } & 69 & 46.3 \\ \text { Undecided } & 52 & 34.9 \\ \text { No } & 28 & 18.8 \\ \text { Total } & 150 & 100\end{array}$

Collective bargaining useful in dispute

Collective bargaining

$\begin{array}{lll}\text { Yes } & 150 & 100\end{array}$

Undecided 0

No $\quad 0 \quad 0$

Total $150 \quad 100$

All agreed on a team approach to healthcare delivery (150, $100 \%)$

\section{Discussion}

Strikes amongst healthcare workers are not rare events in most countries, as is the case in Nigeria. In recent years, there has been an increasing number of healthcare worker strikes across the nation, some national, others regional or state-based [3, 5-10]. It is not surprising to discover that the primary cause of most national healthcare worker strikes in Nigeria is 
Table 7 Bivariate analysis for gender, age and education as against support for strike and hospital leadership rating as dependent variable

\begin{tabular}{|c|c|c|c|c|}
\hline \multirow{5}{*}{ Support for strike } & & \multicolumn{2}{|l|}{ Gender } & \multirow[t]{2}{*}{ Total } \\
\hline & & Male & Female & \\
\hline & Yes & 25 & 40 & 65 \\
\hline & No & 37 & 47 & 84 \\
\hline & Total & 62 & 87 & 149 \\
\hline \multicolumn{5}{|l|}{$X^{2} 0.471, P$ value 0.493} \\
\hline \multirow[t]{3}{*}{ Hospital leadership rating } & Performing to standard & 13 & 26 & 39 \\
\hline & Not performing to standard & 49 & 62 & 111 \\
\hline & Total & 62 & 88 & 150 \\
\hline \multicolumn{5}{|l|}{$X^{2} 1.391, P$ value 0.238} \\
\hline & & \multicolumn{3}{|l|}{ Age } \\
\hline & & $<40$ & $\geq 40$ & \\
\hline \multirow[t]{3}{*}{ Support for strike } & Yes & 54 & 10 & 64 \\
\hline & No & 67 & 15 & 82 \\
\hline & Total & 121 & 25 & 146 \\
\hline \multicolumn{5}{|l|}{$X^{2} 0.180, P$-value 0.671} \\
\hline \multirow[t]{3}{*}{ Hospital leadership rating } & Performing to standard & 29 & 9 & 38 \\
\hline & Not performing to standard & 93 & 16 & 109 \\
\hline & Total & 122 & 25 & 147 \\
\hline \multicolumn{5}{|l|}{$X^{2} 1.619, P$ value 0.203} \\
\hline & & \multicolumn{3}{|l|}{ Education } \\
\hline & & Graduate & Non-graduate & \\
\hline \multirow[t]{3}{*}{ Support for strike } & Yes & 54 & 11 & 65 \\
\hline & No & 65 & 19 & 84 \\
\hline & Total & 119 & 30 & 149 \\
\hline \multicolumn{5}{|l|}{$X^{2} 0.739, P$ value 0.390} \\
\hline \multirow[t]{3}{*}{ Hospital leadership rating } & Performing to standard & 33 & 6 & 39 \\
\hline & Not performing to standard & 86 & 25 & 111 \\
\hline & Total & 119 & 31 & 150 \\
\hline$X^{2} 0.897, P$ value 0.344 & & & & \\
\hline
\end{tabular}

demand for higher salaries and wages. For instance, of the 24-point reason for the 2014 National Medical Association (NMA) doctors' strike, only one made reference to health trust funds to enhance the upgrading of hospitals in Nigeria [16]. The rest focused on doctors' welfare, salaries and wages, career enhancement and other welfare issues. A vital finding from the present study, however, is that poor healthcare leadership and management is deemed to be a more important cause of discontent than personal welfare issues as the root cause of Nigerian healthcare worker strikes (Table 3).

Healthcare workers' strikes also exist in other countries, echoing what was seen in the United States in the 1960s and 1970s, involving the active participation of all categories of healthcare workers and in all kinds of healthcare institutions. In nations where unionism is not compulsory, such as Canada, strikes by healthcare workers are linked to economical, rational, ideological commitment, professional disaffection or social malleability [17]. This is not seen in Nigeria as all healthcare workers, by legislation, are members of one union or the other-sometimes against their will. As suggested by Adebimpe and colleagues, the demand for better salary and welfare was the most common cause of strikes in Lagos, Nigeria, followed by disagreement on a variety of work-related principles [11].

\section{Impact of strikes on patients}

The consequences of strikes on the healthcare system are enormous. Consequences of healthcare workers' strikes in the United States in the 1970s, which Wolfe 
documented in an editorial in the American Journal of Public Health in 1979, included revenue losses to the hospital and increased death on transit, as patients are transferred from one centre to the next [1]. Adebimpe and colleagues in Lagos, Nigeria, had similar findings. In Lagos, they discovered that participants believed that health workers' strikes led to disruption of healthcare services, discharge of patients from hospital without completeness of care and limited care to clients and led to high rate of referrals to private hospitals [11]. In the same vein, Ogunbanjo and Knapp van Bogaert identified two classes of consequences-on the patients and on the healthcare workers [3]. For patients, work loss (if employed), wasted money for transport, treatment delays, prolongation of suffering, irreversible damage to health, dangerous drug interruptions and death were the documented consequences of strikes, while financial gain and improved working conditions which may contribute to less emotional pressure and even a degree of dissuasion from emigrating may be gains of strikes to healthcare workers [3]. This shows that the consequences of healthcare worker strikes are greatly skewed in favour of healthcare workers. However, more work is needed on the economic, societal and political consequences of strikes in Nigeria.

The authors believe that the freedom to choose to be or not to be a member of a union and the freedom to decide to join or not to join a strike action are part of human rights and should be enshrined in the Nigeria Health Act and respected. This may be a useful mitigation against further compulsory strike action. We believe that modalities for the calling for strikes should be reviewed and all workers given equal opportunities to participate in this critical decision (with one man, one vote) so that it does not serve only the purposes of the few in leadership of the unions. We recommend that a general assembly or meeting should be called in which all workers are allowed to vote privately for or against the strikes before strikes are called. Laws should be put in place to support strikes only when more than $60 \%$ of the workers are in favour of the strike action. This is already in practice in many countries of the world and should be replicated in Nigeria [18]. We also believe that strengthening of the health system and appropriate reward systems for healthcare workers require good health management and leadership skills to achieve. To translate this into reality, educating the new and emerging key "physician leaders" should be a fundamental step towards a reformed and revitalized health industry in Nigeria. Although presently, many people are of the view that doctors should continue to lead and head hospitals, we are of the opinion that this monopoly of doctors on healthcare leadership should be reviewed, and only those with prerequisite leadership skills training be appointed to leadership positions. This is without any prejudice to their leadership role in all technical matters concerning patient care. Appointment to managerial/leadership positions should not just be based on number of years in practice nor on technical qualifications but on leadership and management expertise and qualifications.

\section{Recommendations}

It is true that conflicts and confrontations are inevitable in the health industry, but are health workers' strikes the way out? What are some of the ethical and conceptual issues [1]? The International Labour Office, a United Nations agency, refers to essential services as a class of occupations that have been legislated by a government to have special restrictions with respect to labour actions, such as not being allowed to legally strike. Top in this class is the healthcare/hospital sector [19]. To curtail the effects of physicians' strikes in Nigeria, the Medical and Dental Council of Nigeria (MDCN) on 23 June 2011 banned doctors' strikes, because, according to the regulatory body, they cited that it is unethical for doctors to go on strike, as strikes are against the Hippocratic Oath that makes the health of the patient every doctor's first consideration, given that doctors have vowed to always maintain the utmost respect for human life $[20,21]$. However, with the numerous strikes since then by doctors, it shows that they are not willing to respect this guideline. What is more of a concern is MDCN's inability to sanction any doctor despite their published stand on it (except in extreme conditions and with MDCN permission). The body is backed by law but lacks the will to follow through execution of punitive measures on healthcare workers who break the law. Even if the doctors respect this ban, will this eradicate the causes of strikes we identified in this study? The underlying issue is the faulty healthcare system in existence in Nigeria, ranging from ineffective leadership in the healthcare industry, poor working conditions of workers and inadequate infrastructure and equipment. The MDCN cannot sanction doctors who embark on strikes, although the regulatory body is aware of the prevailing poor working conditions. In spite of this, it is critical that healthcare professionals, who are indispensable to the protection of the healthcare and life of patients and the public, not be allowed to withdraw their services from the sick, as abandonment of sick patients should be both an illegal and potentially criminal offence in a just society [1]. To this end, although health workers can (and may) withdraw their services from government, they cannot (and should not) withdraw their services to patients. Other countries have developed systems whereby basic services are not disrupted during strikes but are still being provided by emergency teams, so as to preserve both the right to strike and the 
patients' well-being. This is being practised in Nigeria to a certain extent as emergency services are still being rendered in certain instances during strikes. However, this needs to be expanded as well. It is also critical that the issues raised by this study, particularly health system leadership, be tackled and resolved as part of the twenty-first century healthcare system reforms and healthcare system strengthening. All existing and emerging conflicts should therefore be controlled through concession and compromises from all sides of the divide, while building functional and effective health leadership. As part of solutions proffered for building capacity for health management and minimizing crisis in the health sector, literature shows that the Ethiopian Ministry of Health 2-year Masters in Health Administration (MHA) course is a useful model which could help build skilled healthcare leaders and managers working towards building the kind of healthcare system that the people want $[22,23]$. Nigeria should also adapt the competency frameworks, which have worked in other nations of the world, to develop functional, effective and sustainable healthcare management courses for Nigerian health leaders [24].

The study by Botero et al. stated that richer countries regulate labour less than poorer countries do, although they have more generous social security systems [13]. Is it time, therefore, for Nigeria to deregulate unionism and make it optional to workers, especially in the health industry? Will provision of universal health coverage through a functional national health insurance scheme minimize the frequency of health workers' strikes in Nigeria? There is need for further studies to answer these questions.

\section{Conclusions}

In line with Adebimpe and colleagues' conclusion, although strike actions have more negative than positive effects, and a preventable way of dispute resolution in the healthcare system, they are still very commonly seen in Nigeria. Nigerians should work to minimize strikes while building health leadership that will lead to the development of world-class best practices in the Nigerian health industry. Training doctors in health management and leadership towards building skilled physician leaders is a strategy that is long overdue in Nigeria.

\section{Limitations}

This study was carried out during a health workers' strike. It is possible that this could have led to an element of bias in the responses we received. A second possible source of bias was the fact that the sample population for the study was limited to one state of Nigeria. In addition, a majority of the respondents had less than 5 years' experience in the health system, given that the field workers carrying out the study had limited access to more senior colleagues. It is possible that there may have been a different result if older healthcare workers were included as a larger proportion of the respondents, but the perceptions gained from the younger healthcare workers are still valid, nevertheless. Finally, the sample size of 150 health workers may not have been adequate to power the study to allow for generalization of the findings to a national level. A more inclusive national study is therefore recommended for the future, perhaps with questionnaires administered through national healthcare bodies, such as the West African College of Physicians (WACP).

\section{Abbreviations}

MDCN, Medical and Dental Council of Nigeria; MHA, Masters in Health Administration; NMA, Nigerian Medical Association; SPSS, Statistical Package for the Social Sciences; WACP, West African College of Physicians

\section{Acknowledgements}

SDT-R is grateful to the NIHR Biomedical Facility at Imperial College London for infrastructure support. We are grateful to Mary M.E. Crossey from Imperial College London for useful discussions.

\section{Funding}

Private funds were used for this study.

Availability of data and materials

Data is available for further review on request.

\section{Authors' contributions}

OOO developed the concept, coordinated the research, and wrote and approved the final draft of the article. He also serves as the corresponding author. IPE and OO supported $\mathrm{OOO}$ in the development of the questionnaire and worked on the initial literature review. EPA and DU collated and analysed the data with support from OOO. SDT-R is the guarantor of the article, co-wrote the conclusions and recommendations with 000 and approved the final version. All authors read and approved the final manuscript.

Competing interests

The authors declare that they have no competing interests.

Consent for publication

Not applicable

Ethics approval and consent to participate

Consent was obtained from all participants before their participation in the study.

\section{Author details}

${ }^{1}$ Excellence \& Friends Management Care Centre (EFMC), Abuja, Nigeria. ${ }^{2}$ Hepatology Unit, Imperial College London, 10th Floor, QEQM Building, St Mary's Hospital Campus, South Wharf Road, W2 1NY London, United Kingdom. ${ }^{3}$ No 8, Excellence and Friends Street, Dutse, P. O. Box 200, PSIN901101 Abuja, Nigeria.

Received: 13 May 2015 Accepted: 19 July 2016

Published online: 27 July 2016

References

1. Wolfe S. Strikes by health workers: a look at the concept, ethics, and impacts. Am J Public Health. 1979;69(5):431-3.

2. Encyclopedia of the Nations. Nigeria—working conditions [Online]. (n.d); http://www.nationsencyclopedia.com/economies/Africa/Nigeria-WORKINGCONDITIONS.htmI\#ixzz3Q0J8zoCc. Accessed 10 Apr 2015.

3. Ogunbanjo GA, Knapp van Bogaert D. Doctors and strike action: can this be morally justifiable? S Afr Fam Pract. 2009;51(4):306-8.

4. George Padmore (ed). The voice of coloured labour; speeches and reports of colonial delegates to the World Trade Union Conference, Manchester, PANAF Services Ltd. 1945; Available from https://www.marxists.org/archive/ padmore/1945/labour-congress/. Accessed 10 Apr 2015. 
5. Olatunji S. 'Resident doctors begin warning strike on Wednesday' The Punch Newspaper June 25, 2013 (online). 2013; http://www.punchng.com/news/ resident-doctors-begin-warning-strike-on-wednesday/. Accessed 10 Apr 2015.

6. Hassan J. 'JOHESU strike: issues, resolution and lessons' Daily Independent (online). Posted in: Features September 23, 2013 @ 12:00 am. 2013; http:// www.dailyindependentnig.com/2013/09/johesu-strike-issues-resolutionsand-lessons/. Accessed 10 Apr 2015.

7. Premium Times. 'Fresh strike looms as doctors warn Nigerian government' Premium Times. 2014; http://www.premiumtimesng.com/news/157478-freshstrike-looms-doctors-warn-nigerian-government.html. Accessed 10 Apr 2015.

8. Olokor F. 'NMA suspends warning strike' The Punch Newspaper. 2013; http://www.punchng.com/news/nma-suspends-warning-strike/. Accessed 10 Apr 2015.

9. Obi P. 'BREAKING NEWS...At last, NMA calls off strike' This Day Live. 2014; http://www.thisdaylive.com/articles/breaking-news-at-last-nma-calls-offstrike/187230/. Accessed 10 Apr 2015.

10. Ibeh N. 'Nigerian health workers call off strike' Premium Times. 2015; http:// www.premiumtimesng.com/news/top-news/176152-nigerian-healthworkers-call-off-strike.html. Accessed 10 Apr 2015.

11. Adebimpe WO, Owolade OA, Adebimpe MA. Health worker's perception of the use of strikes as a tool for dispute resolution in Lagos State, Nigeria. J Soc Sci Public Policy. 2010;2:19-23. http://www.cenresinpub.org/strikes.pdf. Accessed 10 Apr 2015.

12. Oleribe OO, Salako BL, Ka MM, Akpalu A, McConnochie M, Foster M, TaylorRobinson SD. Ebola virus disease epidemic in West Africa: lessons learned and issues arising from West African countries. Clin Med. 2015;15(1):54-7.

13. Botero JC, Djankov S, La Porta R, López de Silanes F, Shleifer A. The Regulation of Labor. The Quarterly Journal of Economics. 2004;1 19(4):133982. doi:10.1162/0033553042476215. http://qje.oxfordjournals.org/content/ 119/4/1339.full.pdf+html.

14. Lauritsen $\mathrm{JM}$, editor. EpiData data entry, data management and basic statistical analysis system. Odense Denmark, EpiData Association, 2000-2008. Http://www.epidata.dk. Accessed 13 Apr 2015.

15. IBM Corp. IBM SPSS Statistics for Windows, Version 20.0. Armonk: IBM Corp; 2012.

16. Listed: The 24 reasons Nigerian medical doctors are on strike. http://www. osundefender.org/?p=175535. Accessed 13 Apr 2015.

17. Kravitz RL, Shapiro MF, Linn LS, Froelicher ES. Risk factors associated with participation in the Ontario, Canada doctors' strike. Am J Public Health. 1989:79(9):1227-33.

18. Code of Practice. Industrial action ballots and notice to employers. PL962 (REV2). TO EMPLOYERS. This Code is issued under the power given to the Secretary of State by section 203 of the Trade Union and Labour Relations (Consolidation) Act1992, with the authority of Parliament (resolutions passed on 18 July 2005 by the House of Commons and on 19 July 2005 by the House of Lords). It comes into effect, by order of the Secretary of State, on 1 October 2005. https://www.gov.uk/government/uploads/system/ uploads/attachment_data/file/245421/05-1462-code-ofpractice-industrialaction-ballots-and-notice.pdf.

19. International Labour Organization. Freedom of association-Digest of decisions and principles of the Freedom of Association Committee of the Governing Body of the ILO. 5th ed. 2006. p. 119-20. http://www.lo.org/ wcmsp5/groups/public/—ed_norm/—normes/documents/publication/ wcms_090632.pdf. Accessed 23 Oct 2015.

20. Ohiare O. Medical council bars Nigerian doctors from strike. 2015; http:// www.africanoutlookonline.com/index.php?option=com _ content\&view=article\&id=2166\%3Amedical-council-bars-nigerian-doctorsfromstrike\&ltemid=672. Accessed 13 Apr 2015

21. Anofi D. Medical council outlaws strike for doctors. The Nation. Published on 04/07/2011 06:26:00. 2011. http://www.thenationonlineng.net/2011/ index.php/news/11303-medical-council-outlaws-strike-for-doctors.html. Accessed 13 Apr 2015

22. Kebede S, Abebe Y, Wolde M, Bekele B, Mantopoulos J, Bradley EH. Educating leaders in hospital management: a new model in Sub-Saharan Africa. Int J Qual Health Care. 2010;22 (1):39-43. doi:10.1093/intghc/mzp051.

23. Kebede S, Mantopoulos J, Ramanadhan S, Cherlin E, Gebeyehu M, Lawson R, Bradley EH. Educating leaders in hospital management: a pre-post study in Ethiopian hospitals. Glob Public Health. 2012;7(2):164-74.

24. Wright K, Rowitz L, Merkle A, Reid WM, Robinson G, Herzog B, Baker E. Competency development in public health leadership. Am J Public Health. 2000;90(8):1202.

\section{Submit your next manuscript to BioMed Central and we will help you at every step:}

- We accept pre-submission inquiries

- Our selector tool helps you to find the most relevant journal

- We provide round the clock customer support

- Convenient online submission

- Thorough peer review

- Inclusion in PubMed and all major indexing services

- Maximum visibility for your research

Submit your manuscript at www.biomedcentral.com/submit
Biomed Central 